\title{
The Role of Municipalities in Promoting Well-Being
}

\author{
Inga Jēkabsone ${ }^{1}$, Biruta Sloka ${ }^{2},{ }^{1-2}$ University of Latvia
}

\begin{abstract}
The aim of the paper is to research different approaches to researching and promoting the well-being in municipalities. To achieve the aim, such qualitative and quantitative methods of research as comparing, grouping, graphical analysis, focus group methods will be used. The main results and findings of the paper are: the role of municipalities in promoting well-being is increasing contrary to the role of national or regional authorities, due to the autonomous functions of local authorities, intensive informative links and a wide range of available economic and social instruments.
\end{abstract}

Keywords: municipality, well-being, citizen involvement, community, co-responsibility

\section{INTRODUCTION}

Well-being of society is an ancient issue - all societies try to find the best possible solutions for ensuring community welfare. Recently, when new approaches to studying community wellbeing are being developed, it is very important to analyse the process of evaluating it. The idea of measuring community or local government well-being is relatively new. It reflects the international activities as well as grassroots efforts by business leaders, activists, local politicians and other stakeholders to develop approaches that can help gather information to inform local decision-makers. Nowadays, a local government is becoming more and more important in ensuring the well-being of the society, implementing the co-responsibility approach in decision-making and public participation processes in resolving topical local issues. These problems are on research agenda also for academic researchers. Undertaking activities aimed at promoting a community's future well-being and choosing indicators that can assess both the current and future state of that well-being are excellent opportunities for a community to articulate its values and goals and to foster community involvement.

Taking into account the above-mentioned considerations, the object of the research is the approaches to well-being in municipalities.

The aim of the paper is to research different approaches to researching and promoting well-being in municipalities.

To achieve the aim, such qualitative and quantitative methods of research as comparing, grouping, graphical analysis, and focus group methods will be used.

The main tasks of the paper are:

- to research good practice in researching well-being at local municipal level;

- to analyse different methods of research of the well-being at local municipal level;

- to indicate certain principles of ensuring the well-being in the municipality.

\section{THEORETICAL BACKGROUND}

Within the theoretical framework, the role and importance of local authorities in promoting well-being at local level as described in different strategic documents, legal normative acts, and scientific research will be analyzed. Subsequently, the methodology used in different municipalities to research and promote well-being at local level will be reviewed, as well as good practices of researching and promoting well-being system in different municipalities.

\section{A. Institutional and administrative framework for promoting well- being at local level}

In Europe 2020, which is the European Union's main strategy for putting Europe's economy back on the path to growth, turning the EU into a smart, sustainable and inclusive economy delivering high levels of employment, productivity and social cohesion [13], certain information regarding the role of local government in promoting well-being is not provided. For adapting this strategy for local authorities, a special handbook was prepared, which is a part of the follow-up to the opinion of Committee of the Regions on the role of Local and Regional Authorities (LRAs) in achieving the objectives of the Europe 2020 Strategy. The Opinion stipulates that “(...) the Committee of the Regions urges the Commission to launch jointly with the Committee of the Regions (CoR) a broader communication campaign in order to raise the awareness of Europe 2020 on the part of local and regional decision-makers and the public. For this purpose, the CoR proposes that a "Handbook on the Europe 2020 strategy for cities and regions" be drawn up with the Commission in order to clearly explain how they can contribute to the implementation of the strategy, while showing the various sources of financing" [29].

In addition, the CoR's Europe 2020 Monitoring Platform has been organised, which is a network of local and regional authorities that aims to assess the Europe 2020 Strategy from the point of view of the EU Regions and Cities. It supports the diffusion of multilevel policymaking for growth and jobs by facilitating the exchange of information and good practices between local and regional policy makers. All regions and cities and their associations can contribute to the CoR's work on Europe 2020 by taking part in the surveys of the Europe 2020 Monitoring Platform [10].

Many associations for local governments at world and EU level have been organized in order to share experience of ensuring well-being of the society, such as ICLEI - Local Governments for Sustainability, which is an association of over 1,220 local government members who are committed to sustainable development. It provides technical consulting, training and information services to help build capacity, share knowledge and support local government in the implementation of sustainable development at local level [20]. Another 
organisation is UCLG - United Cities and Local Governments, which represents and defends the interests of local governments on the world stage, regardless of the size of the communities they serve. The organisation's stated mission is to be the united voice and world advocate of democratic local self-government, promoting its values, objectives and interests, through cooperation between local governments, and within the wider international community [40]. At the EU level, this function is performed by REVES - European Network of Cities and Regions for the Social Economy, which represents and promotes the common values of its members at the European and international institutions. It aims to establish a dialogue with the Institutions to develop a social and solidarity based economy, to exchange expertise and know-how, and to implement innovation in the fields of inclusion, participation and the empowerment of local communities. It brings together representatives of cities and regions as well as social economy organisations [14].

The main regulation of the Republic of Latvia for governing the work of the municipalities is the Law on Local Governments. Although the Law on Local Governments does not speak directly about the role of municipality in promoting the well-being of the population in the municipality, implicitly but clearly it is indicated in Paragraph 15, where the functions of the municipalities are laid down, which form the basis for municipality operating and budgeting. The statutory functions of the municipalities such as public utility organization, administration of territory, the mobilization of citizens' education, care for culture, health care and social assistance [28], etc., are obviously related to ensuring the well-being of local residents.

\section{B. The role of local governance in promoting well-being}

The functions of local governance have been laid down in different legal acts of each country.

In [37] it is considered that the role of each local government is under threat because of wider societal and economic developments, and that the strongest democracies are those in which municipalities have a number of different functions.

The empirical and normative nature of the concept of governance and its implications for well-being at the local level have been explored. Several studies on "good governance" [24] and numerous comprehensive comparative analyses (e.g. O'Riordan and Voisey [34], Lafferty [26], PASTILLE [21], Gahin [17], Evans [15], Dluhy and Swartz [12]) formed the framework for evaluating the role of well-being in the context of local governance. In addition, nowadays the concept of sustainable development has been taken into account, which has been developed within the comparative institutional study on governance structures by Swanson and Pintér [39], Bellagio Principles [35] and the renewed Bellagio STAMP principles [35] as well as research of Mineur [30] proposed to develop, monitor and assess sustainability indicators in the context of ensuring well-being.

\section{Methodology of researching well-being at local level}

Researching the well-being of citizens, it should be remembered that the society does not exist in isolation. It is a part of some city, region and country. The physical, economic and social links of citizens with the authorities are significant for the development of the society, its viability and sustainability [4].

Researching well-being in the municipality, the term "community well-being" is often used, because communities are often place-based - citizens of certain municipality feel related to their administrative territory - so-called local patriotism or localism is observed as being characteristic of the citizens of certain municipality.

The concept of community well-being dates back to the beginnings of public health initiatives in the $19^{\text {th }}$ century. The idea of researching community well-being in a more holistic way (e.g. three dimensions - social, economic and environmental) was developed subsequent to the Brundtland Commission in the late 1980s and early 1990s, as the idea of sustainable development was popularized. Since measuring well-being began, indicators of economic well-being have been predominant [33].

The idea of community indicators of well-being reflects a change in focus from the "top down" imposition of what wellbeing, sustainability, quality of life, etc. are, to a "bottom-up" approach that emphasizes democratic participation and empowerment in the development of locally significant understanding of well-being and its measurement [16]. The movement towards measuring community well-being also reflects several other recent trends including

1) the devolvement of control for many programs at the local scale (e.g. social programs),

2) the need to measure Agenda 21 achievements,

3 ) the recent emphasis on the need for better performance and accountability indicators (e.g. measuring the outcome of spending on social programs) [36].

In terms of community well-being, indicators are used to assess the social, environmental and economic dimensions of well-being. The information provided by these indicators allows decision-makers - individuals, governments, businesses, etc. - to make decisions and get feedback regarding the progress achieved with respect to well-being. Indicators can present a snapshot of the current situation and measure change over time (profile indicators). They can also provide information regarding how the current well-being status developed and/or could be influenced in the future (process indicators) [38].

In addition, indicators [16] provide the opportunity:

- to encourage democratic participation in visioning a community's goals;

- to measure progress towards achievement of these goals;

- to raise awareness and focus attention on community priorities;

- to provide feedback and accountability mechanism for decision-makers;

- to choose actively future desired outcomes.

Undertaking activities towards visioning a community's future well-being and choosing the indicators that can assess both the current and future state of that well-being are excellent opportunities for a community to articulate its values and goals and to foster community involvement. As outlined by 
Sustainable Seattle [22], the indicators chosen by the community to report about itself reflect its collective values and inform about the situation to be considered in decision-making. The idea of citizens choosing the indicators that reflect these values, rather than these indicators being imposed by an outside agency, is an intensely democratic opportunity that values grassroots public participation.

\section{Good practice in researching well-being at local level}

Indicators of community well-being, sometimes called "benchmarks" or "vital signs", are now used extensively by nation-states, regional governments, urban and rural areas, and even neighbourhoods [3]. The Community Indicators Consortium lists and provides links to community well-being projects from around the world, including sixteen from Canada alone [7]. In the United States there are over two hundred municipalities, using some form of community well-being measurement [16]. One of the earliest and ongoing examples of efforts to track well-being is Jacksonville, Florida's, Community Council Quality of Life indicator program. The council tracks one hundred indicators of well-being covering nine themes [2]. Other well-known examples include Sustainable Seattle [22] and Sustainable Calgary [25]. Thus, the current state of knowledge about indicators is both in-depth and extensive. What still remains challenging is how to "more effectively translate knowledge and commitment into action" in order to achieve the desired changes to community well-being [5].

Another direction in researching well-being is to measure the quality of life (QOL), especially it has been used in researching urban areas, as over $80 \%$ of European citizens live in urban areas. In addition, the cities are at the same time centers of production, innovation, employment, and culture, and loci of segregation, deprivation, and ethnic conflict. Amongst the notable most recent surveys are the works of Craglia [9], Mulligan [31], Mulligan and Carruthers [32] and Lambiri, Biagi, and Royuela [27].

In Latvia territory development index (TDI) has been developed, which has been used for the assessment of development of different territorial units for ten years already. In addition, this index is also used in assessment of well-being at local level. TDI is a generalised indicator, which is calculated with determined weight coefficients by summing up standardised values of the most important basic indicators of statistics which characterise development. It demonstrates higher or lower development of the territories with respect to the average social economic development level of the state in the relevant year. The initial data for calculations of development index shall be taken from the Central Statistical Bureau, Treasury, State Land Service, State Employment Agency and Office of Citizenship and Migration Affairs using the statistical indicators accumulated during a year (GDP, amount of personal income tax, non-financial investments) and statistical indicators of the moment (demographic indicators) in accordance with the status at the beginning of the year to be reviewed. The development level index characterises the development level in the relevant year demonstrating higher or lower development of the territories with respect to the average level in the state, but development level change index characterises the changes of the development level in comparison to the previous year, showing falling behind or overtaking development of the territories from the average development level in the previous year [11]. Territorial development index is applied in elaboration of the regional development state support programme; differentiation of support within the framework of measures co-financed by the European Union Funds; the assessment of impact of the EU, state support and other financial instruments on the territorial development and assessment of economic efficiency; the comparison, assessment, forecasting of the development of different territories and in the analysis of territorial development of other type; and the determination of the territories to be specially supported [6].

The standardized indicators are calculated considering the initial indicators, expressed in human, monetary, percentages or other actual units. As the result of standardization, the initial measurement units are lost; therefore, different indicators become mutually comparable. Technically, it is done by subtracting the arithmetic average from the specific indicator for the specific territory and by dividing the result by the standard deviation of the respective indicator. It is further possible to calculate the weighted arithmetic average of all standardized indicators used in all calculations or the territory development index for each territory and to rank all the territories according to the sequence of these indexes.

TABLE I

INDICATORS AND THEIR WEIGHT VALUES USED TO CALCULATE TERRITORY DEVELOPMENT INDEX

\begin{tabular}{|c|c|c|c|c|}
\hline No & Indicator $^{2}$ & Weights & Relation to well-being & $\begin{array}{l}\text { Usage in } \\
\text { well-being } \\
\text { index }\end{array}$ \\
\hline 1 & $\begin{array}{l}\text { Unemployment } \\
\text { level }\end{array}$ & 0.3 & $\begin{array}{l}\text { There is high correlation between } \\
\text { unemployment and well-being }\end{array}$ & $\begin{array}{l}\text { It is } \\
\text { reasonable } \\
\text { to use it as a } \\
\text { well-being } \\
\text { indicator }\end{array}$ \\
\hline 2 & $\begin{array}{l}\text { Personal } \\
\text { income tax } \\
\text { revenues in the } \\
\text { local } \\
\text { government } \\
\text { budget per } \\
\text { capita, LVL }\end{array}$ & 0.3 & $\begin{array}{l}\text { As it is not possible to make } \\
\text { estimates of GDP at the local } \\
\text { government level, this indicator } \\
\text { could objectively, albeit indirectly, } \\
\text { indicate the income level of } \\
\text { inhabitants. This figure is also } \\
\text { precisely determined. Of course, it } \\
\text { should be taken into account that in } \\
\text { many municipalities, especially } \\
\text { near big cities, there is a declaration } \\
\text { problem, namely, people actually } \\
\text { live and work near a big city, while } \\
\text { they are registered in remote } \\
\text { municipalities. The underground } \\
\text { economy should be taken into } \\
\text { account, thereby the value of the } \\
\text { indicator will always be more or } \\
\text { less artificially low. However, it is } \\
\text { worth considering that the } \\
\text { municipalities with a higher } \\
\text { amount of personal income tax } \\
\text { per capita also have higher } \\
\text { standard of living. }\end{array}$ & $\begin{array}{l}\text { It is } \\
\text { reasonable } \\
\text { to use it as a } \\
\text { well-being } \\
\text { indicator }\end{array}$ \\
\hline
\end{tabular}




\begin{tabular}{|c|c|c|c|c|}
\hline 3 & $\begin{array}{l}\text { Demographic } \\
\text { burden }\end{array}$ & 0.2 & $\begin{array}{l}\text { This indicator shows average } \\
\text { number of persons under and over } \\
\text { working age per } 1,000 \text { population } \\
\text { of working age. This means that in } \\
\text { municipalities with a greater } \\
\text { demographic burden persons of } \\
\text { the working age "provide for" } \\
\text { more children and pensioners. } \\
\text { However, a higher proportion of } \\
\text { children could mean higher } \\
\text { standard of living as new families } \\
\text { choose to live in a region with a } \\
\text { higher level of well-being. }\end{array}$ & $\begin{array}{l}\text { It is } \\
\text { questionable } \\
\text { to use it as a } \\
\text { well-being } \\
\text { indicator }\end{array}$ \\
\hline 4 & $\begin{array}{l}\text { Change in the } \\
\text { number of } \\
\text { population } \\
\text { during the last } \\
5 \text { years }\end{array}$ & 0.2 & $\begin{array}{l}\text { It takes into account the fact that } \\
\text { migration mostly takes place in } \\
\text { the direction from the area with a } \\
\text { lower standard of living to the } \\
\text { area with a higher living standard. } \\
\text { Thus, it is reasonable to assume } \\
\text { that in the areas where there is a } \\
\text { positive change in the number of } \\
\text { permanent residents, there is also } \\
\text { a higher level of well-being. }\end{array}$ & \begin{tabular}{|l|} 
It is \\
reasonable \\
to use it as a \\
well-being \\
indicator
\end{tabular} \\
\hline
\end{tabular}

Source: Elaborated by the author based on [3]

As it is illustrated in Table 1, it is rather questionable to use a certain index in measuring well-being at local level as demographic burden does not directly relate to well-being.

One of the successful approaches how to research well-being in municipalities is using the so-called SPIRAL (Societal Progress Indicators for the Responsibility of All) methodology, recently developed by the experts from the Council of Europe under supervision and inspiration of Samuel Thirion, which provide the way to define and measure well-being from the subjective point of view of the persons themselves. It is a common set of fundamental values for society's progress towards the improved capacity to ensure the well-being of all through the development of co-responsibility. This methodology also ensures that such progress is jointly made with inhabitants and other social stakeholders at local level, tying it with the regional, national, European and global levels. A community of experimenters (governments and other local and regional players, companies, hospitals, schools, associations, NGOs, researchers, etc.) was involved in developing this methodology, which expanded little by little in order to produce the methodology and make it available to as many people as possible [8]. SPIRAL methodology was approbated in 8 different European municipalities within URBACT II programme project "TOGETHER for territories of co-responsibilities" - Salaspils (Latvia), Mulhouse (France), Braine-L'alleud (Belgium), Pergina (Italy), Kavala (Greece), Covilha (Portugal), Botkyrka (Sweden), Debica (Poland). After approbation in these cities, the range of the cities where this methodology was used also increased [42]. By collecting the answers to open-end questions, such as "What is well-being for you?", "What is ill-being for you?", "What do you do or could do for well-being?" the indicators and their evaluations were gained, they are the main outputs of the methodology. The indicators are divided in 8 main groups: 1 . Access to means of living; 2. Living environment; 3. Relations with institutions; 4. Personal relations; 5. Social balance; 6. Personal balance; 7. Feelings of well-being/ill-being; 8. Attitudes and initiatives
[40]. The software designed by the Council of Europe updates the results of homogenous group findings, the experts put in the citizens' written criteria data, allocating them in the right indicator group and giving estimates.

\section{RESEARCH RESULTS}

Taking into account the studies described above and the experience of the researchers in approbating the methodology for studying well-being at local level, paying particular attention to the SPIRAL methodology that was approbated in 8 different European municipalities within ERAF URBACT II programme project "TOGETHER for territories of coresponsibilities" [18], [19] a framework for evaluating the role of local governance in the context of well-being is proposed; it is illustrated in Table 2 .

TABLE II

CONCEPTUAL FRAMEWORK TO EVALUATE THE ROLE OF LOCAL GOVERNANCE IN THE CONTEXT OF WELL-BEING INDICATORS

\begin{tabular}{|c|c|c|}
\hline $\begin{array}{c}\text { Local } \\
\text { Government } \\
\text { Role }\end{array}$ & Criteria & Result Indicator \\
\hline \multirow[t]{3}{*}{$\begin{array}{l}\text { Assigning } \\
\text { overall } \\
\text { responsibility }\end{array}$} & $\begin{array}{l}\text { Political } \\
\text { commitment }\end{array}$ & $\begin{array}{l}\text { High support and commitment } \\
\text { from the Mayor or the executive } \\
\text { political board }\end{array}$ \\
\hline & $\begin{array}{l}\text { Sensitivity to } \\
\text { change }\end{array}$ & $\begin{array}{l}\text { Indicators not vulnerable to } \\
\text { political shifts (strong } \\
\text { institutionalisation) }\end{array}$ \\
\hline & $\begin{array}{l}\text { Sectoral } \\
\text { coordination }\end{array}$ & $\begin{array}{l}\text { Strong horizontal coordination and } \\
\text { integration of activities and policies } \\
\text { within local government } \\
\text { departments (promoted by the } \\
\text { indicators) }\end{array}$ \\
\hline \multirow[t]{2}{*}{$\begin{array}{l}\text { Government } \\
\text { coordination }\end{array}$} & $\begin{array}{l}\text { Regional } \\
\text { coordination }\end{array}$ & $\begin{array}{l}\text { Strong vertical integration with other } \\
\text { government levels in indicator- } \\
\text { related projects or sustainable } \\
\text { development policies }\end{array}$ \\
\hline & Training & $\begin{array}{l}\text { Different training programmes } \\
\text { regarding indicators and } \\
\text { sustainable development issues }\end{array}$ \\
\hline \multirow[t]{3}{*}{$\begin{array}{l}\text { Stakeholders' } \\
\text { involvement }\end{array}$} & $\begin{array}{l}\text { Multi } \\
\text { stakeholder }\end{array}$ & $\begin{array}{l}\text { Broad involvement of different } \\
\text { stakeholders outside the local } \\
\text { government }\end{array}$ \\
\hline & $\begin{array}{l}\text { Participation } \\
\text { mechanisms }\end{array}$ & $\begin{array}{l}\text { Large number of } \\
\text { mechanisms/techniques to promote } \\
\text { the participation of different } \\
\text { stakeholders }\end{array}$ \\
\hline & $\begin{array}{l}\text { Feeling of } \\
\text { ownership }\end{array}$ & $\begin{array}{l}\text { Strong feeling of ownership by the } \\
\text { stakeholders }\end{array}$ \\
\hline \multirow{2}{*}{$\begin{array}{l}\text { Link with local } \\
\text { planning } \\
\text { documents }\end{array}$} & Performance & $\begin{array}{l}\text { Strong integration of the indicators } \\
\text { in the targets of local plans/strategies }\end{array}$ \\
\hline & Funding & $\begin{array}{l}\text { Solid local budgets and stable } \\
\text { funding schemes }\end{array}$ \\
\hline $\begin{array}{l}\text { Link with } \\
\text { (inter)national } \\
\text { networks }\end{array}$ & Learning & $\begin{array}{l}\text { Close involvement in other } \\
\text { national/international indicator- } \\
\text { related projects }\end{array}$ \\
\hline $\begin{array}{l}\text { Communication } \\
\text { with society }\end{array}$ & Communication & $\begin{array}{l}\text { road and different communication } \\
\text { channels }\end{array}$ \\
\hline
\end{tabular}

As it is illustrated in Table 2, the main roles of local government in the context of ensuring well-being include assigning overall responsibility, ensuring government 
coordination, involving different stakeholders, linking with planning documents, as well as with national and international networks and communicating with society. As the functions by specific areas are defined in different legal acts (like ensuring education, communal services, etc.), those roles should be assumed as general principles in everyday work providing wellbeing for inhabitants.

Those roles of local governments in providing well-being for the citizens provide principles for well-being for all. In this context a certain methodology with certain activities should also be prepared. It should be implemented by local governments at preliminary research stage, research stage and implementation stage. In several publications by the authors the research methodology for well-being using the main principles of the above-described SPIRAL methodology was described [23]. In this paper the focus is made on the implementation stage, which follows the research, within which several wellbeing indicators were collected using focus group methods and special software, which allows categorizing different criteria mentioned by inhabitants. The implementation stage consists of different steps, such as:

1. Drawing Local Action Plan. When the results of research on well-being are prepared for a certain municipality, those results should be presented to the inhabitants of the municipality. For the purpose of convenience, a group of different stakeholders should be formed, who would represent the interest of certain groups within the municipality, for example, the leaders of NGOs, interest groups, unions and other organizations. This social organization could be called Local Support (LSG) group and can be used as a permanent organization which represents the interests and needs of the society. After presentation of results to LSG, certain activities, which should be implemented in order to improve certain indicators of well-being, should be de indicated. Those activities should be proposed by LSG in cooperation with the administration of the municipality. It is most important to ensure that LSG is co-responsible for the implementation of those activities, namely, those activities should be performed by the citizens. For example, "Organising the city festival" could be a proposed activity for improving the indicator "Culture events" where the main organisers could be NGOs in coordination with certain municipality employees (for administrative and financial support). The activities could be indicated also using focus group methods.

2. Approval of Local Action Plan. Afterwards, when all activities are indicated and approved by LSG, the Local Action Plan should be approved by municipality government. In addition, it should also be incorporated in the work plans of the municipality and municipal budget. The proposed incorporation in the context of Latvian municipalities is presented in Fig.1.

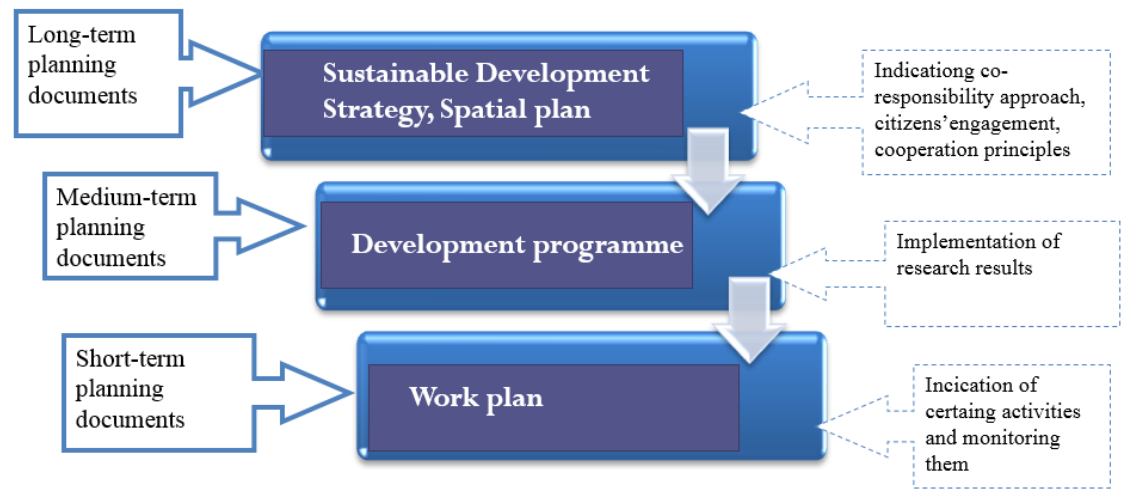

Fig. 1. Incorporation of the methodology for researching and improving well-being in municipalities within different planning documents (Latvian municipality case)

Source: Elaborated by the authors

3. Implementation and monitoring of Local Action Plan. As for short-term and medium-term planning documents, the responsible persons, budget and time limit, as well as output indicators should be indicated. All activities should be implemented in close cooperation with the citizens of the municipality.

4. Assessment of results. By the end of the year all activities should be reviewed - which of them were implemented and whether there were some delays. It is proposed that the Local Action Plans should be drawn for medium-term, specifying the activities for the current year and updating the plan afterwards. After 3-4 years the research on well-being should be repeated to assess if certain indicators of well-being have improved.

The methodology described was developed, applied and approbated in Salaspils Municipality (Latvia). It has been observed that the proposed methodology cannot be universal researching and promoting well-being in municipalities should be adapted to local conditions. However, several principles, which should be taken into account in every democratic society, have been defined:

- focus on participation and process - dialogue about wellbeing is a key element of the process of community building and commitment to democratic participation, the process of maintaining dialogue about community wellbeing has the potential, in and of itself, to contribute to community well-being;

- agree on what is important to measure - choosing indicators reflects the community's values;

- measure what is important rather than what is easily measurable - make sure the indicator captures the wellbeing issue that is being measured; 
- honest reporting of results - if the community well-being reporting exercise is to contribute to decision-making and community enhancement, all generated information should be publicly reported;

- continually review the relevance of indicators - as the community changes over time, it may be necessary to develop new indicators to measure particular aspects of well-being or repeat the research;

- understand the level of resource commitment - broader and longer-term projects will require a larger and on-going commitment of resources including money, time and personnel. Decide what level of commitment is right for your community.

- choose indicators that can inform decision-making indicators that can support and inform the development of new policies, programs or activities;

- need to incorporate research results within planning documents - all principles and activities that promote well-being in municipality should be fixed in the planning documents of a certain municipality, including work plans of administration of municipality and municipality budget.

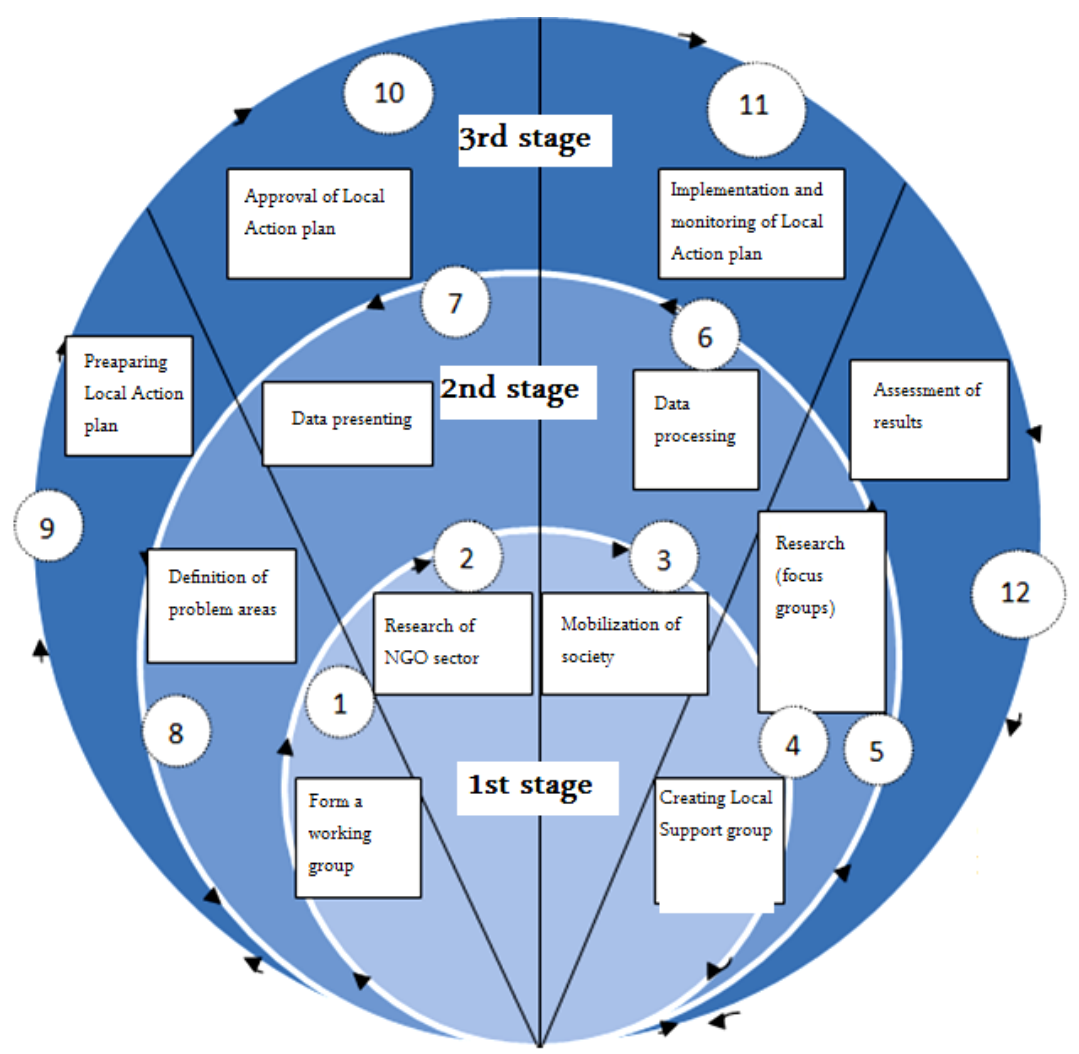

Fig. 2. The sequence of researching and promoting well-being methodology in municipalities Source: Elaborated by the authors

All those principles should be taken into account if the need to promote well-being of community is established - in the beginning it is more effective to study the problems of a certain municipality which does not demonstrate a high level of wellbeing, to define certain indicators that describe the situation in each area and afterwards to implement certain activities in order to promote well-being, including the citizens of municipality at every stage.

Practical realisation of the approach mentioned above in Salaspils municipality indicated that it promotes mutual understanding among different groups of inhabitants as well as the management of the municipality.

\section{CONCLUSIONS}

The role of the municipality in promoting well-being is increasing contrary to the role of the national or regional authorities due to the autonomous functions of local authorities, intensive informative links and a wide range of available economic and social instruments.

One of the most appropriate methods how to measure wellbeing at local level is using indicators as they allow decisionmakers to make decisions and get feedback regarding the progress achieved with regard to well-being. They can also provide information regarding how the current well-being status developed and/or could be influenced in the future.

Research showed that increasing the well-being of community is inextricably linked to the citizens' involvement in decision-making process using the so-called coresponsibility approach - it means that the process of increasing well-being is done in close cooperation with community. Comparison of results of several countries has confirmed that community involvement in municipality decision-making promotes supportive attitude of the community to municipality decisions and better understanding of decisions taken by the municipality. 
Apart from the measuring well-being at municipal level the process of promoting well-being according to results of wellbeing research in certain municipality is also important. The conducted research should lead to concrete activities aimed to improve the well-being - these activities should be developed and implemented in close cooperation with the citizens using the so-called co-responsibility approach. In order to ensure more significant progress, different techniques to increase the participation of society should be used, which is one of the key factors to success. Research results, activities and the main principles should be incorporated in different planning documents of certain municipalities, as well as the methodology of measuring subjective well-being should be repeated to evaluate the progress of different indicators of well-being.

\section{REFERENCES}

[1] 2012 Quality of Life Progress Report for Jacksonville and and Northeast Florida. Reference Document [Online] Jacksonville Community Council Inc, 2012 - [Accessed 27.09.2013.]. Available: http://www.jcci.org/images/QOL/2012_qol_ref_doc.pdf

[2] A Community Indicators Case Study: Addressing the Quality of Life in Two Communities [Online]. Redefining Progress 1999 - [Accessed 06.09.2013.]. Available: http://www.rprogress.org/publications/1999/CI_CaseStudy1.pdf

[3] Amendments to the Cabinet regulations No 482 25.05.2010. "Regulations on the Territorial development index calculation procedure and its values", Latvijas Vēstnesis, No 85, 31.05.2012.

[4] Andrews, F. J. Parental perceptions of residential location: Impacts on children's health, Health \& Place, 2009, N 16, pp. 252-258.

[5] Besleme, K., Maser, E., Silverstein, J. A Community Indicators Case Study: Addressing the Quality of Life in Two Communities, [Online] Redefining Progress, 1999 - [Accessed 03.08.2013.]. Available: http://www.rprogress.org/publications/1999/CI_CaseStudy1.pdf

[6] Cabinet Regulations No. 840 'The criteria and procedures for allocation of government grants for local governments and planning regions for implementation of European Union Structural Funds and the Cohesion Fund co-financed projects", Latvijas Véstnesis. N 147, 28.07.2009.

[7] Community Indicators Consortium: A Global Community of Practice, Indicator Efforts [Online]. Community Indicators Consortium, 2011 [Accessed 16.08.2013.]. Available:

http://www.communityindicators.net/INDICATOR.EFFORTS.htm

[8] Council of Europe. Well-being for all. Concepts and tools for social cohesion. Trends in social cohesion, N 20, 2008, Council of Europe, 182 p.

[9] Craglia, M., Leontidou, L., Nuvolati, G., Schweikars, J. Towards the development of QoL indicators in the digital city. Environment and Planning B: Planning and Design, 2004, N 31, pp. 51-64. http://dx.doi.org/10.1068/b12918

[10] Delivering on the Europe 2020 Strategy. Handbook for Local and Regional Authorities [Online]. EU Committee of the Regions, 2011 [Accessed 10.09.2013.]. Available:

https://portal.cor.europa.eu/europe2020/SiteCollectionDocuments/Europ e\%202020202020\%20Handbook\%20for\%20Local\%20and\%20Regional $\%$ 20Authorities.pdf

[11] Development of Regions in Latvia 2009 [Online]. State Regional Development Agency, 2009 - [Accessed 03.08.2013.]. Available: http://www.vraa.gov.lv/uploads/Development_of_Regions_2009.pdf

[12] Dluhy, M., Swartz, N., Connecting knowledge and policy: the promise of community indicators in the United States. Social Indicator Research, 2006, N 79, pp. 1-23.

[13] Europe 2020: A European Strategy for smart, sustainable and inclusive growth [Online]. European Commission, 2010 - [Accessed 23.09.2013]. Available:http://ec.europa.eu/eu2020/pdf/COMPLET\%20EN\%20BARR OSO $\% 20 \% 20 \% 20007 \% 20-\% 20$ Europe $\% 202020 \% 20$ \%20EN\%20version.pdf

[14] European Network of Cities and Regions for the Social Economy. Charter [Online]. REVES, 2006 - [Accessed 15.09.2013.]. Available: http://www.revesnetwork.eu/public/reves-charter.pdf

[15] Evans, B., Joas, M., Sundback, S., Theobald, K. Governing Sustainable Cities. Earthscan, London, 2005, 288 p.
[16] Gahin, R., Paterson, C. Community Indicators: Past, Present, and Future, National Civic Review, 2001, N 90, vol. 4, pp. 347-360. http://dx.doi.org/10.1002/ncr.90406

[17] Gahin, R., Veleva, V., Hart, M. Do indicators help create sustainable communities? Local Environment, 2003, N 8, vol. 6, pp. 661-666. http://dx.doi.org/10.1080/1354983032000152752

[18] Grantiņš, A., Sloka, B., Jēkabsone, I. Municipality and inhabitants cooperation for well-being: Salaspils district case. International conference "NEW CHALLENGES OF ECONOMIC AND BUSINESS DEVELOPMENT - 2012" Proceedings, University of Latvia, 2012, pp. 241-250.

[19] Grantiňš, A., Sloka, B., Jēkabsone, I., Vladimirova, J., Kantāne, I., Vaivade, A. Well - Being: Analysis of Different Approaches - Salaspils District Case. International conference "CURRENT ISSUES IN MANAGEMENT OF BUSINESS AND SOCIETY DEVELOPMENT 2011" Proceedings, University of Latvia, 2011, pp. 172-180.

[20] ICLEI: Local Governments for Sustainability. Charter [Online]. ICLEI, 2011 - [Accessed 21.09.2013.]. Available: http://www.iclei.org/fileadmin/user_upload/ICLEI_WS/Documents/Gov ernance/Charter_approved_FINALforCOUNCIL20110912.pdf

[21] Indicators into action - local sustainability indicator sets in their context [Online], PASTILLE, 2002 - [Accessed 05.09.2013.]. Available: http://www.ocs.polito.it/alpcityruo/dwd/indicatori/8.pdf

[22] Indicators of Sustainable Community: A status Report on Long-term Cultural, Economic and Environmental Health for Seattle/King County [Online]. Sustainable Seattle, 1998 - [Accessed 12.08.2013.]. Available: http://www.sustainableseattle.org/Programs/RegionalIndicators/1998Ind icatorsRpt.pdf

[23] Jekabsone, I., Thirion, S., Grantiňš, A., Sloka, B. , Challenges of the SPIRAL Methodology for Well-Being Studies”. International conference „NEW CHALLENGES OF ECONOMIC AND BUSINESS DEVELOPMENT 2013" Proceedings, University of Latvia, 2013, pp. 339 - 353.

[24] Jordan, A. The governance of sustainable development: taking stock and looking forwards. Environment Planning, 2008, N 26, vol. 1, pp. 17-33. http://dx.doi.org/10.1068/cav6

[25] Keough, N. Citizens and Sustainability: Something Real and Lasting Sustainable Calgary Community Sustainability Indicator Project Outcomes [Online]. Sustainable Calgary Society, 2007 - [Accessed 30.08.2013.]. Available: http://sustainablecalgary.org/wpcontent/uploads/2012/03/SC_IndicatorProjectOutcomes.pdf

[26] Lafferty, W. M. Governance for Sustainable Development: the Challenge of Adapting Form to Function. London: Edward Elgar, 2004, 250 p. http://dx.doi.org/10.4337/9781845421700

[27] Lambiri, D., Biagi, B., Royuela, V. QoL in the economic and urban economic literature. Social Indicators Research, 2007, N 84, pp. 1-25. http://dx.doi.org/10.1007/s11205-006-9071-5

[28] Law on Local Governments of the Republic of Latvia. Latvijas Vēstnesis, 09.06.1994, No. 61-192.

[29] Markkula, M. Opinion of the Committee of the Regions on 'The role of local and regional authorities in achieving the objectives of the Europe 2020 strategy. Official Journal of the European Union, 2012, N 9, p. 53-60.

[30] Mineur, E. Towards Sustainable Development: Indicators as a tool of local governance. PhD Thesis. Umeå University Print and Media, Umea, Sweden, 2007.

[31] Mulligan, G., Carruthers, J., Cahill, M. Urban quality of life and public policy: A survey. Roberta. Capello, Peter. Nijkamp (Eds.), Urban dynamics and growth: Advances in urban economics, Amsterdam: Elsevier, 2004, pp. 729-802.

[32] Mulligan, G., Carruthers, J.I. Amenities, QoL and regional development. RW. Marans, RJ. Stimson (Eds.), Investigating quality of urban life, Springer, Dodrecht, 2011, pp. 107-134.

[33] Murphy, B. Community well-being: an overview of the concept [Online] Toronto: Vulear Waste Management's Organozation, 2010 - [Accessed 29.03.2013.]. Available: http://www.nwmo.ca/uploads_managed/MediaFiles/ 1681_researchsupportprogram_communitywellbeingoverview.pdf

[34] O'Riordan, T., Voisey, H. The transition to Sustainability: the politics of Agenda 21 in Europe. London: Earthscan, 1998, 220 p.

[35] Pintér, L., Hardi, P., Martinuzzi, A., Hall, J. Bellagio STAMP: principles for sustainability assessment and measurement, Ecology Indicators, 2012, $\mathrm{N} 17$, pp. 20-28.

[36] Ramos, O., Jones, K. 2005, Comprehensive Community Indicator Systems, National Civic Review, 2005, N 2, pp. 74-77; http://dx.doi.org/10.1002/ncr.99

[37] Stoker, G. Was Local Governance Such a good idea? A global Comparative Perspective. Public Administration, 2011, N 1. vol. 89, p. 15-31. 
http://dx.doi.org/10.1111/j.1467-9299.2011.01900.x

[38] Sustainability Starts in Your Community: A Community Indicators Guide [Online]. Redefining Progress and Earth Day Network, 2002 - [Accessed 07.09.2013.]. Available: http://www.rprogress.org/publications/2002/ciguide.pdf

[39] Swanson, D., Pintér, L. Governance Structures for National Sustainable Development Strategies - Study of good practice examples [Online]. International Institute for Sustainable Development, Winnipeg, 2006 [Accessed 16.08.2013.]. Available: http://www.iisd.org/pdf/2006/measure_gov_structures.pdf

[40] The URBACT Guide to Local Action Plans EAP/MC. [Online] URBACT II, 2009 - [Accessed 13.09.2013.]. Available: http://urbact.eu/ fileadmin/Projects/HERO/.../Vilnius_LSG_LAP_GUIDE.pdf

[41] United Cities and Local Governments. Strategic Priorities 2010-2016 [Online]. UCLG, 2009 - [Accessed 01.09.2013.]. Available: http://issuu.com/uclgcglu/docs/strategic_priorities.pdf

[42] URBACT II Programme Manual EAP/MC. [Online] UBACT II [Accessed 13.09.2013.]. Available: http://mdrl.ro/_documente/coop_ teritoriala/granite_URBACTII_OfficialDoc/URBACT_II_Programme_ Manual_V_10_-_100608.pdf

Inga Jēkabsone received B. sc. admin., M. sc. admin. in management from the University of Latvia in 2011 and 2013 respectively, currently is she is a doctoral student at the University of Latvia.
She is presently a Project Manager at the State Regional Development Agency at Latvia-Lithuania cross-border cooperation programme. In addition she has working experience in local and regional development, working at Salaspils Municipality, and as research assistant at the University of Latvia, has experience in work with foreign experts, including representatives from the Council of Europe.

She has published several publications on the research and promotion of the well-being system in Latvia, she has participated in international scientific conferences, presenting the results of measuring the well-being in municipalities in Latvia.

Telephone and e-mail address: +371 27116147; jekabsone_inga@inbox.lv

Biruta Sloka. Dr. oec. University of Latvia, educational background economist-mathematician, gained experience in Aaarhus University (Denmark), Dalhousie University (Canada), Oklohama State University (USA), Agder University (Norway), etc.

Biruta Sloka currently is a professor at the University of Latvia, had experience in work at the Ministry of Economics and the Ministry of Education and Science, was a coordinator of many international conferences and lead several research projects.

Biruta Sloka is a member of the Association of Latvian Statisticians, Association of Professors of Latvian Higher Education Institutions, Association of Econometrists, Association of Hydrogen.

Telephone and e-mail address: +371 9244966; biruta.sloka@lu.lv

Inga Jēkabsone, Biruta Sloka. Pašvaldību nozīme labklājības veicināšana

Labklājības jēdziens ir bijis nozīmīgs vienmēr - katra sabiedrība cenšas atrast iespējami labāko veidu, kā nodrošināt augstāku labklājības līmeni. Līidz ar to tiek pētīti arvien jauni veidi, kā novērtēt labklājības līmeni, kas kḷūtu par pamatu labklājības paaugstināšanas sistēmas izveidei. Ideja par labklājības novērtēšanu vietējā līmen̄i ir saistīta ar dažādām starptautiskām aktivitātēm, kā arī vietējo politiḳu, aktīvistu un attīstīiāju pūlēm efektīiāk izmantot resursus, kā arī administratīvos un finanšu instrumentus. Mūsdienās vietējā pārvaldība kḷūst arvien nozīmīgāka labklājības nodrošināšanā pašvaldības iedzīvotājiem, ieviešot t.s. līdzatbild̄̄bas pieeju lēmumu pieṇemšanā, veicinot sabiedrības iesaistīšanos svarīgu lēmumu pieṇemšanā pašvaldības līmenī. Aktivitāšu veikšana, kas vērsta uz pašvaldības nākotnes labklājības līmeṇa paaugstināšanu, izvēloties indikatorus, kas var novērtēt gan tagadnes, gan nākotnes situāciju, sniedz pašvaldībai iespējas noteikt tās mērḳus un to sasniegšanai nepieciešamo rīcības plānu.

Nemot vērā iepriekšminēto, šī raksta mērkis ir pētīt dažādas labklājības novērtēšanas un paaugstināšanas iespējas pašvaldībās.

Lai sasniegtu mērḳi, tika izmantotas dažādas kvantitatīvas un kvalitatīvās pētījumu metodes, tādas kā salīdzināšana, grupēšana, grafiskā analīze, fokuss grupu metode.

Galvenie šī raksta rezultāti ir saistāmi ar labās prakses apkopošanu labklājības izpētē, dažādu metožu analīzi labklājības pētī̌sanā, kā arī noteiktu principu formulēšanu labklājības veicināšanai vietējā (pašvaldības) līmenī. Tika secināts, ka labākais veids, kā novērtēt labklājību pašvaldībā, ir indikatoru noteikšana, kuri lauj novērtēt dažādas labklājības iez̄imes, kā arī iesaistīt pašvaldības iedz̄ivotājus labklājības novērtēšanā un veicināšanā.

Инга Екабсоне, Бирута Слока. Роль самоуправлений в повышении благосостояния

Концепция благосостояния была всегда актуальна - каждое общество пытается найти наилучший способ обеспечить более высокий уровень жизни. Следовательно, исследовались новые способы оценки уровня благосостояния, которые бы стали основой для развития системы повышения благосостояния. Идея оценки благосостояния на местном уровне связана с различными международными мероприятиями, а также с усилиями местных политиков, активистов и разработчиков, указывая на необходимость более эффективного использования ресурсов, также административных и финансовых инструментов. В настоящее время местное самоуправление становится все более значимым в обеспечении уровня жизни местных жителей за счет так называемого подхода совместной ответственности в процессе принятия решений, поощряя участие местного населения в принятии основных решений. Деятельность, которая фокусируется на обеспечении более высокого уровеня жизни местных жителяей в будущем путем выбора показателей, которые могут оценить как настоящее и будущее положение благосостояния, предоставляет возможность местным самоуправлениям устанавливать свои цели и необходимого для их достижения плана действий.

В связи с вышеизложенным целью статьи является изучить различные возможности оценки и повышения благосостояния жителей для местных самоуправлений.

Для достижения цели были использованы различные количественные и качественные методы исследования, как сравнение, группировка, графический анализ, метод фокус-групп.

Основные результаты этой статьи - сбор лучшей практики об исследовании благосостояния на местном (муниципальном) уровне, анализ различных методов изучения благосостояния на местном уровне, а также формулировка принципов исследования благосостояния на местном (муниципальном) уровне. Был сделан вывод, что лучшим способом для измерения благосостояния местного самоуправления является определение показателей, которые позволяют оценить различные особенности благосостояния, а также вовлечение население в повышение благосостояния местного самоуправления. 